\title{
Sociological Analysis of the Relation Between the Uses of Virtual Social Networks and Life Style of the Young (Case Study of Facebook and the Young of Isfahan)
}

\author{
Soraya Memar \\ Assistant professor in Sociology, University of Isfahan \\ E-Mail:s.memar@Itr.ui.ac.ir \\ Samad Adlipour \\ E-Mail: Samadadlipour@gmail.com \\ Ezzatollah Khosravi \\ E-Mail:Khosravia89@yahoo.com
}

\section{Doi:10.5901/mjss.2013.v4n6p469}

\section{Abstract}

\begin{abstract}
Today the societies have sure changed through communication advancement and have made lots of changes in culture and daily lives of people. It can be said that new media Have impact on the life styles and general tastes of people. It seems that the growth of The number of internet users and internet social networks has created a new life style Among the young called "virtual life style" this life style integrated with virtual social Networks influence all daily activities. The purpose of the present research is analysis of Changes in the life style of the young created by introduction and popularity of virtual Social networks. the present study was conducted through survey, available and Voluntary sampling and online researcher-made questionnaire. Statistical population of the study consisted of all face book users in Isfahan. The results of the study suggest that there is difference between life style of the people who are members in face book and people who are not it should be said shopping pattern and cultural consumption of the people differ according to their membership or non-membership however, nutrition pattern and body management have no relation With membership in face boo. The duration of connection of face book has greatly affected nutrition pattern.
\end{abstract}

Ke words: Virtual social networks, Facebook, life style, Body management, Free-time, Cultural consumption.

\section{Introduction}

A lot of people call the present age "the age of communication and information Revolution" .the age in which mass media have changed into the most complex for Inspiring thoughts and the most effective weapon for soft conquering of the societies. In the recent decades, regarding extremely rapid pace of the growth and advancement Of information and communication technology, complexity and efficiency of these Means are growing in the world. Complexity and expansion of human societies in the current Modern societies have caused the existence of mass media in social relation of the men To be unavoidable.

In the past, people had face to face relation and the ways of living through these types of relation weren't so common and popular. However, regarding modern technologies. It can be said that hyper power of technology has caused the Human societies to communicate online and style and ways of a new life are changing in all over The world.

Today the societies have sure changed due to communication advancement communicative informative technologies like satellite, internet and virtual social networks have found a good position in societies and made lots of changes in culture and daily lives. Life style is a concept used in the modern world and applied in different fields due to its expansion. Life style was presented as prominent concept sociology during 1980sand more in social theories and lots of social scientists have expressed their views about it. Giddens states that life style can be considered more or less as a comprehensive combination of the functions applied by a person to meet his/her needs as well as to embody special 
interpretation that he/she has selected for his /her personal identity to others.

People living in modern societies embody their personal identity in their life styles. Thus life style is attached to modernity and since it requires selection, it's meaning less in traditional cultures. Because in the lives of people in the past, there was no choice practically. Customs and traditions presented a pre-determined plan that had to be implemented through a type of hidden force. However, people have a variety of choice in the new world.

Rapid growth and popularity of new technologies in daily life, the abundance of new available ways for communicating and getting access to information have expanded the range of the means by which people can from their culture, life styles and daily identities. Among communicative-informative technologies, virtual social networks like facebook can be considered as a suitable means for analysis of a transformation process that simultaneously includes people (daily life, culture, life style and identity), information and informative technologies.

Today virtual social networks, as omnipresent and perpetual media are expanding rapidly in our society due to their potential and actual capabilities. Rapid expansion and popularity of virtual social networks have raised some questions about their possible consequences on users and society. The appearance of the great technological innovation has caused economical and social changes and created a new life style. So it can be said people not only use this technology to achieve their aims but also this technology changes people according to specific principles of its function.

In today world, internet social networks have transformed into a place for the presence of social strata specially the young to exchange their views and though and meet their needs according to their social lives. Social networks are a source for meeting lots of social and culture needs of their members. In addition, they enable the members to pursue their own activities in these virtual communities and do other social activities through computer or cell phone simultaneously. In this field Jessica Hilberman (2009) believe that "today lots of the young have network social activities and use cyber relations to make their own lives. Activity in social networks includes all aspects of life. In fact, internet social networks have changed the life style of the young more than the of other traditional groups. So one interesting point is that how the young form their own identity and life style in social networks. Since about $60 \%$ of our society are the young, their relation with social networks like face book and their effective on the lives of the young, regarding the expansion of the social networks deserve special attention. So the purpose of the present research is analysis of the changes made in the life style of the young through introduction and popularity of the virtual social networks. In other words, the crucial issue in the present study is face book and its consequences on the life style of the young.

\section{Research Background}

Bashir and Afrasiabi (1391) in their study under the title of "virtual social network and lifestyle of the young" applied surrey and online questionnaire and concluded there was relation between membership in virtual social network and the way of devoting time to other social activities. Also membership had relation with categories such as the way of communication with the opposite sex, the way of members' communication in outside world. So it can be said there is relation between membership in virtual social network and life style of the young.

Shahnooshi and Taji (1391) studied the impact of social network and the life style of the young in Shahrekord. The results show that there is no relation between life style and type of network, residential place and value solidarity. However, there is meaningful relation between life style and the variables of sex, education level, relational solidarity and social gathering.

Jennifer Marie Almjeld (2008) applying content analysis of a group made in "Myspace" by female student of a highschool in Midostren showed that how membership and participation in "Mylspace" change life style of the members of internet social network. Also she concluded that there was relation between membership and participation in internet social networks and the kind of messages and photos published by the members.

\section{Concepts}

\subsection{Life style}

We start our discussion with Simmel's view. He has lots of statements about life style and its meaning. Simmel presents these interpretations in a form of discussion about form and style and its encounter with content and life. He stat life style is embodiment of human attempt to find basic value his supreme individuality in his objective culture and introducing it to the other. In other word, human select the forms of his manner for his intended meaning (supreme individuality). Simmel calls capability of such a choice taste and calls these related forms life style (Mahdavi Kani, 1386:205). Simmel believes 
life style is objectivation of the subjective in the form of known social forms. It's a kind of expression of supreme and unique individuality in the form that the other (or others) understand this uniqueness. (Simmel, 1990: 463). As a result, accepting the difference between forms (possible manners in the form of objective culture) and meaning (supreme individuality), Simmel relates life style that is selected forms theirs arrangement to meaning. If we want to present a definition based on Simmel's various expression, this as follow: life style is all related forms that people of a society select for their lives based on their inner motivations and tastes and through their attempt to balance their subjective personality and human, objective biological environment.

By assessment of Veblen's works, we can't achier an explicit definition of this term. Veblen considers life style as a pattern of collective behavior. These behaviors are like social customs and rituals and ways of thinking. He also says life style is behavioral of mental mechanism, habits of thinking and cognition. (Mahdavi Kani, 1386: 205). Weber doesn't offer an accurate definition interpretations have been presented in the form of definition.

In an article Denis Rang states (about Weber's views) "by life style Weber means common values and custom that give a sense of collective identity to the group. He doesn't mean a way or style of living that is selected freely because of its agreement with psychological needs of place" (Tavasoli,1389 :62).About Weber's views, J.Mckee (1969) expresses "what Weber calls life style refers to the way that classes and groups of the same rank create from a type of life. In other words, it's a pattern of cultural manner and a combination of beliefs. Every social class cultivates its own life style and displays a distinct ideology. A way of looking at life that expresses its special social experiences and its relation with other social groups". So Weber doesn't believe life style equals social stratum. But he states life style is an indicator of social stratum. In other words, it is something that determines the unknown borders of social stratum and social position. Weber believes life style is like manner led by tendencies and life chances pare the way for it to be expressed (Henry et al., 1381: 231).

Wenzel (1982) defines life style as "totality of behavioral patterns and normative inclinations ... that evolve through social processes" (Henry et al., 1381 :232). About life style, G. Leslie and et al (1994: 368) state "the manners related to credit and prestige stratification are called life style. Life style is not only the manners a person has but also it's the way of expressing them by the same person. Life style includes both consumption patterns and the power gained through them. Taste, communication rituals and fashion are symbols of having a place in social ladder. Chaney (1996: 4) believes that life style can be considered patterns of actions that distinguish people of a society.

Pierre Bourdieu is one of the sociologists who has enriched the concept of life style. In his view (1984:172), life style are regular products of cultural capital that change into the systems of the symbol of social ranks.

In Bourdieu's theory, life style including classified actions and classifying a person in different fields such as dividing hours, the kind of entertainment and sports, communication ways, house and furniture and etiquettes of speaking and walking, is in fact embodiment and objectivity of the person's preferences. On one hand, life styles are consumption ways of social agents that have different ranks in the respect of social dignity and legitimacy. These consumption ways reflect hierarchical social system. However as Bourdieu shows in the book "Distinction on the base of dialectical logic", consumption isn't just an only way to show distinction but it's a way to create distinction as well. So life style is a systematic product of manner that is understood through its mutual relation with manner principles and changes into a system of signs that is assessed based on each society (for example respectable, disgraceful, etc) (Kaffashi et al., 1389: 125).

As Bourdieu refers in the above phrase, consumption is considered as a system of signs and symbols that has functions like social distinction (Shalchi, 1386: 100-101). Bourdieu (1984) in the book "Distinction" analyzed some ways by which groups of the same rank and class distinguish themselves from other consumption groups. He shows that how special groups, specially economical-social classes, make same choices of different goods, styles of clothing and eating, wearing makeup, furniture, interior design, etc. To determine their life style and distinguish themselves from others (Fazeli, 1382: 42).

Bourdieu believe that there is a constant challenge for gaining power and dignity not only among but also inside different classes of society. These challenges occur in social space where the relation among the classes are built based on the amount and access to different forms of capital. He refers to challenge and fight for going power; the challenge that not only is related to economy but also includes cultural domination. Challenge and fight among classes and subclasses to gain domination; result in the continuation of life style changes. Symbolic fight is in the field of different cultural preferences. So social space of life styles is built on the base of rules and regulations of power. As a result, more powerful classes and sub-classes make life style prominent and dominant (Razavizade, 1386: 55-56). Also post modern theorists including Baudrillard, Gibbins and Reimer consider life style as the main feature of post modern society. Life style is often "expressive". People introduce themselves to the surrounding world through life style. It means life style is 
expressed through appearance (clothing style and manner) as well as through actions and deeds (choosing free time activities), objects (choosing house furniture) and trough choosing friends (Gibbins \& Reimer, 1381: 104).

In fact life style is a part of life that is realized practically and includes complete range of the activities that people do in their daily lives. So the range of different activities of people in different fields of life can built their life style in the same field.

In the present research, life style includes cultural consumption, free time activities, body management, shopping patterns and nutrition patterns.

\subsection{Virtual social network}

Advancement of information technology has changed man's way of recording history. This change has influenced the way of communication among people. Social networks as one of the most important means with their capabilities and facilities not only have a deep impact on social aspect of the users in different societies but also have lots of applications in different fields including education, medicine and low (Hariri and Anbari, 1390: 2). A social network is a combination of web-based services that enables people to create public and personal profiles for themselves, communicate with other members of the network, share their source and kook for new links among other public profiles (Donah et al., 2008: 23). On the base of another definition, virtual social networks are online services that allow people to have their own profiles in a definite and clear system, introduce themselves to others, share their information and communicate with others. Thus people can stay in touch with the others and form new social relations (Boyd and Ellison, 2008: 212). In fact social networks have been designed to increase and boost social relations in virtual space. Generally communication is facilitated through the information placed on the people's profiles like photo, personal information and interests (all of them provide some information about a person's identity). Users can see the profiles of the others and communicate through different functional programs like e-mail and chat (Tiffany et al., 2009: 228).

Overall, it can be said social networks are the sites that present the users with the feature of sharing through adding some features like chat and e-mail and others one to a simple site like search engine. Social networks are the place where hundred millions of internet users gather to communicate and exchange information regardless of border, language, sex and culture (Soltanifar, 1389: 53). A social network is a website that allow people and organizations to create their own pages. Then it enables them to link their pages on the base of different things they have in common.

Social networks based on their activities have other options like internet news readers, on line games, uploading videos and computer files and communicate with other personal media. Thus we can see the users can have access to different facilities in social networks. However, in the past they had to refer to several websites to have access to them. That's why the users spend most of their time in social networks?

Now we introduce the social network of face book that is one of the most popular sites in the field of combination and enhancement of the present social relations as well as formation of new social groups. Face book is a social site that was founded by Mark "Zuckerberg" in February 4, 2004. In this site you can share your photos, film or messages with other people have using account. This is considered as the number one site in the respect of the number of the users as well as in expert's view and in a word, in the respect of its own filed.

Facebook space is considered as a circle of the friends and acquaintances of a user. Accepting a large number of members, this site enables the users to add new friends to their old ones. The users of face book can share their photos, send messages, tag the pictures for themselves or the others, write on their own walls or the ones of the others, become member of the groups, make new groups, share their views in group discussion, make or accept different kinds of request and play in facebook.

\section{Theoretical Frame work}

In the current world, living in the style of internet social networks is rapidly increasing due to the expansion of the culture of member ship in virtual social networks especially among the young. This state has been created because of increasingly jump in the number of social network users. In daily relation we usually communicate with people who are involved in our daily activities. These relations can be face to face, trough messages, phone call and going to a place with that person. These relations that we usually do in our daily lives. However, it seems that an increase in the number of internet users and internet social networks have created a new life style among the young called virtual life style. In fact the interest of the young in membership in virtual social networks due to their attractive structure and satisfying their 
social needs requires us to pay attention to the relation between membership and presence in internet social networks and the life style of the young.

Regardless of conducting any survey, it's possible to prove a relation between membership and presence in internet social networks and life style of the young in the frame work of Ameli's theory of "dual globalization" and Castelle's theory of "network society". Ameli believes due to the appearance and expansion of simultaneous relation industry and internet as a global communicate-informative network a new space in life has been created that can be called "second space" or "virtual space". This second space has provided a new space for the human life.

This view believes that the most significant change in the contemporary world that is the base of future changes is competition of real and virtual worlds (Ameli, 1387). In fact virtual world attempts to put everything in electricity flow and make the categories of the real world digital (Ameli, 1387). Ameli states that today communicative and informative technologies have changed everything and redefined them. "The current society is experiencing a new type of networking due to simultaneous relation industry. Wirelessness of communicative and informative industries have created a new type of network society" (Ameli, 1388: 5). In Castells's view the network society people are constantly communicating to improve social structure. In such circumstances, people's dependence on internet and virtual social networks causes web accomplishments to be crucial and enhance the position of using internet and virtual social networks. Ameli believes networking of current society has rethought all things and everything and created new concept. This has redefined the concepts like family, friends, relation and even trivial issues like the style of greeting.

Dual globalization theory has paved the way for analysis of the function of internet social network users in relation with their life style. Based on this theory, the appearance of a virtual world parallel to the physical world has caused five combinations that have created significant and paradigmatic changes in life space. They are as follows:

1) The men's relations have become physical-virtual that means they aren't limited any more by rage and constraint of time and physical space due to the expansion of applying informative technological instruments specially internet based informative instruments.

2) Time has become physical-virtual that means the concept of time has changed in "dual globalization" world that enjoys simultaneous geometrical capacity and result in accumulation of time capacities.

3) Culture has become physical-virtual that means it's independent of geography based features and it enjoys the features of pace and rapid more.

4) Work has become physical-virtual that means following numeric logic that result in complete value of time contrary to physical work that reflects whole time necessary for doing work.

5) Belonging and dependence have become physical-virtual that means a capacity has been created as big as the whole world for movement of population and social and culture belonging.

Becoming physical-virtual is a process that has made dual globalization dominant in all aspects of human life. People in such a space face and become familiar with a social world and then values, norms and new issues because they live in their own houses globally and are exposed to new relations day and night (Ameli, 1388: 23)

So applying this theory, we can clarify how virtual social networks users are exposed to the change of cultural symbols related to life style through presence in dual globalization space. It also shows how they express the effects of presence in virtual social networks through the type of their relation and features related to the frame of user page in virtual society and how they display some of the effects on their lives in external world.

The theory of network society has shown the effects of internet social networks on all aspects of life and state how internet social networks can change the life style of people? Castells states "the cost that must be paid to enter this system (virtual societies) is adapting to its logic, language, inputs and coding and decoding system. That's why this system has such an important role in different social effects that a horizontal communicative network with various centers like internet should be made instead of a central multi-media system (Castells, 1390: 433). This Casstell's statement show emphasis on the extrance of relation between membership and presence in social networks and cultural indicators related to life style. He emphasize" for new societies, banning the entrance to this system, using password for the flow and publication of messages in the whole system are important cultural challenges that their outcomes pre-determine the result of symbolic conflicts of the current world. In new system frame work of domination and freedom process in informative societies are greatly determined by this issue that who are active and passive users of the networks (Castells, 1390: 433). Finally the result of expansion of virtual societies is transformation of human life in a way that areas will lose their cultural, historical geographical meaning and are included in functional networks and visual collages. 


\section{Research plan and Hypotheses}

In the present research to answer the question "what kind of relation is there between using virtual social networks and life style?" two hypotheses were raised. They are as follow:

1) Life style of people and its dimensions differ according to membership or non-membership in facebook.

2) Duration of membership in face book and the amount of using it influence people life style and its dimensions.

\section{Research Methodology}

On line questionnaire was applied in this survey because virtual space doesn't have a special place in the real world and its virtual and among computers. Also it's not possible to have access to all different users of face book in the world due to geographical dispersion and it's more acceptable and efficient to study a face book user in virtual space. Statistical population of this study consisted of face book young users in Isfahan. In this survey, available and voluntary sampling was applied due to mentioned reasons and lack of definite sampling frame work and dispersion of statistical population. In fact the questionnaire was send to about 5000 face book users in Isfahan. In the next stage, out of completed and returned questionnaires, 381 questionnaires were studied according to the definition of statistical population and after deleting the problematic ones.

\subsection{Validity and Reliability of Research Instruments}

In the present research, Cronbach's alpha coefficient was applied to test reliability of the questionnaire. For most of variables, Cronbach's alpha coefficient was more than 0/7. Table 1 shows the result.

Table 1. Cronbach's alpha coefficient of questionnaire variables

\begin{tabular}{|l|l|c|c|}
\hline Variable & Dimensions & Number of items & Cronbach's alpha \\
\hline \multirow{4}{*}{ Life style } & Cultural consumption & 10 & $75 \%$ \\
\cline { 2 - 4 } & Free time activities & 8 & $75 \%$ \\
\cline { 2 - 4 } & Body management & 12 & $76 \%$ \\
\cline { 2 - 4 } & Shopping patterns & 11 & $77 \%$ \\
\cline { 2 - 4 } & Nutrition patterns & 8 & $73 \%$ \\
\hline
\end{tabular}

\section{Findings}

Findings of the research are presented in two sections: Descriptive section that offers a description of users' features. Inductive section was devoted to the research hypotheses testing.

\subsection{Descriptive Findings}

Table 2. Frequency distribution of the respondents based on age group and sex

\begin{tabular}{|c|c|c|c|c|c|c|c|}
\hline & \multicolumn{4}{|c|}{ Age group } & \multirow{2}{*}{ total } \\
\hline & & & Under20 & $21-24$ & $25-29$ & Over30 & \\
\hline \multirow{4}{*}{ sex } & \multirow{2}{*}{ male } & number & 36 & 117 & 93 & 24 & 270 \\
\hline & & Percent & $13.3 \%$ & $43.3 \%$ & $34.4 \%$ & $8.9 \%$ & $100 \%$ \\
\hline & \multirow{2}{*}{ female } & Number & 6 & 39 & 51 & 15 & 111 \\
\hline & & Percent & $5.4 \%$ & $35.1 \%$ & $45.9 \%$ & $13.5 \%$ & $100 \%$ \\
\hline \multirow{2}{*}{ total } & & Number & 42 & 156 & 144 & 39 & 381 \\
\hline & & percent & $11 \%$ & $40.9 \%$ & $37.8 \%$ & $10.2 \%$ & $100 \%$ \\
\hline
\end{tabular}

Generally over $29 \%$ off the respondents are men and about $71 \%$ of them are women. As table 2 displays the most respondent have been in age group of 21-24 and 25-29 and other belong to the age group of under 20 and over 30 .

Table 3 displays the state of cultural consumption (cultural affairs) of the young users of face book. The result suggest that the most face book users prefer to see social dramas and spiritual films and use artistic works to decorate 
their rooms or houses. High percentages (over 30\%) of face book users never visit painting, photo or calligraphy galleries and don't participate in art classes.

Table 3. Studying the state of cultural consumption (cultural affair) of face book young users.

\begin{tabular}{|l|c|c|c|c|c|c|c|}
\hline & $\begin{array}{c}\text { Using artistic } \\
\text { works to } \\
\text { decorate your } \\
\text { room or house }\end{array}$ & $\begin{array}{c}\text { Changing the } \\
\text { decoration of } \\
\text { your room or } \\
\text { house }\end{array}$ & $\begin{array}{c}\text { Participation } \\
\text { in art } \\
\text { classes }\end{array}$ & $\begin{array}{c}\text { Going } \\
\text { to } \\
\text { concert }\end{array}$ & $\begin{array}{c}\text { Going to } \\
\text { movie } \\
\text { theater }\end{array}$ & $\begin{array}{c}\text { Visiting galleries } \\
\text { of painting, photo } \\
\text { and calligraphy }\end{array}$ & $\begin{array}{c}\text { Seeing social } \\
\text { dramas and } \\
\text { spiritual films }\end{array}$ \\
\hline Very much & $11.8 \%$ & $8.7 \%$ & $3.1 \%$ & $3.9 \%$ & $1.6 \%$ & $3.1 \%$ & $12.6 \%$ \\
\hline Much & $41.7 \%$ & $27.6 \%$ & $12.6 \%$ & $11.0 \%$ & $18.9 \%$ & $10.2 \%$ & $45.7 \%$ \\
\hline little & $22.0 \%$ & $33.9 \%$ & $31.5 \%$ & $33.1 \%$ & $42.5 \%$ & $27.6 \%$ & $32.3 \%$ \\
\hline Very little & $17.3 \%$ & $22.0 \%$ & $20.5 \%$ & $23.6 \%$ & $25.2 \%$ & $27.6 \%$ & $8.7 \%$ \\
\hline never & $7.1 \%$ & $7.9 \%$ & $32.3 \%$ & $28.3 \%$ & $11.8 \%$ & $31.5 \%$ & $0.8 \%$ \\
\hline
\end{tabular}

In the table 4, the state of cultural consumption (music consumption) of the young users of face book has been studied. The result of the table show that most of face book users listen to pop music and Iranian traditional music. High percentage (over $44 \%$ ) of face book users never listens to mental music.

Table 4. State of cultural consumption (music consumption) of face book young users

\begin{tabular}{|l|c|c|c|c|c|c|c|}
\hline & Rap & Heavy mental & Jazz & Rock & Pop & $\begin{array}{c}\text { Classical and } \\
\text { Folk music }\end{array}$ & $\begin{array}{c}\text { Iranian } \\
\text { traditional music }\end{array}$ \\
\hline Very much & $3.9 \%$ & $3.1 \%$ & $3.9 \%$ & $5.5 \%$ & $20.5 \%$ & $12.6 \%$ & $20.5 \%$ \\
\hline Much & $13.4 \%$ & $11.0 \%$ & $13.4 \%$ & $17.3 \%$ & $52.8 \%$ & $33.9 \%$ & $40.9 \%$ \\
\hline Little & $29.9 \%$ & $15.0 \%$ & $29.1 \%$ & $24.4 \%$ & $18.1 \%$ & $34.6 \%$ & $26.0 \%$ \\
\hline Very little & $33.9 \%$ & $26.8 \%$ & $27.6 \%$ & $29.1 \%$ & $7.1 \%$ & $11.8 \%$ & $7.9 \%$ \\
\hline never & $18.9 \%$ & $44.1 \%$ & $26.0 \%$ & $23.6 \%$ & $1.6 \%$ & $7.1 \%$ & $4.7 \%$ \\
\hline
\end{tabular}

In table 5. The state of cultural consumption (cultural expenses) has been studied. Results suggest that most face book users prefer to spend money on book, shoes and clothes. 5.5\% of the users never spend money on computer softwares. About $5 \%$ of the users never spend money on sanitary and make up stuff.

Table 5. State of cultural consumption (cultural expenses) of the young users of face book.

\begin{tabular}{|l|c|c|c|c|}
\hline & $\begin{array}{c}\text { Sanitary and } \\
\text { make up stuff }\end{array}$ & $\begin{array}{c}\text { Computer soft } \\
\text { wares }\end{array}$ & Book & $\begin{array}{c}\text { Shoes and } \\
\text { clothes }\end{array}$ \\
\hline Very much & $13.4 \%$ & $3.9 \%$ & $32.3 \%$ & $22.0 \%$ \\
\hline Much & $35.4 \%$ & $24.4 \%$ & $44.1 \%$ & $52.0 \%$ \\
\hline Little & $31.5 \%$ & $48.0 \%$ & $17.3 \%$ & $23.6 \%$ \\
\hline Very little & $15.0 \%$ & $18.1 \%$ & $5.5 \%$ & $2.4 \%$ \\
\hline never & $4.7 \%$ & $5 . .5 \%$ & $0.8 \%$ & $0 \%$ \\
\hline
\end{tabular}

In table6. The state of nutrition pattern of young users of face book has been studied. The results show that most face book users prefer national and Iranian foods. About $16 \%$ of face book users never eat foreign food.

Table 6. State of nutrition pattern of young users of face book

\begin{tabular}{|l|c|c|c|c|}
\hline & Foreign foods & Fast foods like pizza, sandwich & Iranian foods & Local foods \\
\hline Very much & $1.6 \%$ & $3.9 \%$ & $41.7 \%$ & $10.2 \%$ \\
\hline Much & $8.7 \%$ & $26.8 \%$ & $55.1 \%$ & $29.9 \%$ \\
\hline Little & $36.2 \%$ & $39.4 \%$ & $2.4 \%$ & $32.3 \%$ \\
\hline Very little & $37.8 \%$ & $27.6 \%$ & $.8 \%$ & $19.7 \%$ \\
\hline never & $15.7 \%$ & $2.4 \%$ & $0 \%$ & $7.9 \%$ \\
\hline
\end{tabular}


In table7. State of free time of the young users of face book has been studied. The results show that they prefer to use face book or discuss different topic with their friends in their free time. Large percentages of face book users never participate in political or religious activities in their free time.

Table 7. State of free time of face book young users

\begin{tabular}{|l|c|c|c|c|c|c|c|c|}
\hline & $\begin{array}{c}\text { To } \\
\text { rest }\end{array}$ & $\begin{array}{c}\text { To play } \\
\text { game } \\
\text { and } \\
\text { sport }\end{array}$ & $\begin{array}{c}\text { To use } \\
\text { virtual } \\
\text { social } \\
\text { network } \\
\text { face book }\end{array}$ & $\begin{array}{c}\text { To use } \\
\text { internet }\end{array}$ & $\begin{array}{c}\text { Non- } \\
\text { school } \\
\text { studying }\end{array}$ & $\begin{array}{c}\text { To } \\
\text { participate } \\
\text { in political } \\
\text { activities }\end{array}$ & $\begin{array}{c}\text { To } \\
\text { participate } \\
\text { in religious } \\
\text { activities }\end{array}$ & $\begin{array}{c}\text { Discussing } \\
\text { different } \\
\text { topics with } \\
\text { friends }\end{array}$ \\
\hline Very much & $14.2 \%$ & $10.2 \%$ & $33.1 \%$ & $45.7 \%$ & $18.1 \%$ & $.8 \%$ & $2.4 \%$ & $29.9 \%$ \\
\hline Much & $40.9 \%$ & $33.1 \%$ & $30.7 \%$ & $40.2 \%$ & $32.3 \%$ & $10.2 \%$ & $5.5 \%$ & $45.7 \%$ \\
\hline Little & $37.0 \%$ & $32.3 \%$ & $22.0 \%$ & $12.6 \%$ & $29.1 \%$ & $18.1 \%$ & $26.8 \%$ & $19.7 \%$ \\
\hline Very little & $6.3 \%$ & $20.5 \%$ & $6.3 \%$ & 0 & $17.3 \%$ & $21.3 \%$ & $21.3 \%$ & $2.4 \%$ \\
\hline never & $1.6 \%$ & $3.9 \%$ & $7.9 \%$ & $1.6 \%$ & $3.1 \%$ & $49.6 \%$ & $44.1 \%$ & $2.4 \%$ \\
\hline
\end{tabular}

In table 8.state of nutrition patterns, body management and shopping pattern have been studied. Result suggest that more than $10 \%$ of face book users pay attention to nutrition pattern and agree with its main principles like eating breakfast, fruits and vegetable and daury.16.5\% face book users ignore shopping pattern and disagree with its principles buying brands, following fashion and shopping in luxurious shopping center. About body management some users agree and as many as supporters, some disagree with beauty make up and surgeries.

Table 8. State of nutrition pattern, body management and shopping pattern of face book young users

\begin{tabular}{|l|c|c|c|}
\hline & Nutrition pattern & Body management & Shopping pattern \\
\hline Strongly agree & $10.2 \%$ & $1.6 \%$ & $3.9 \%$ \\
\hline Agree & $16.5 \%$ & $7.1 \%$ & $1.6 \%$ \\
\hline Neither agree nor disagree & $65.4 \%$ & $80.3 \%$ & $77.2 \%$ \\
\hline Disagree & $7.1 \%$ & $10.2 \%$ & $16.5 \%$ \\
\hline Strongly disagree & $.8 \%$ & $.8 \%$ & $.8 \%$ \\
\hline
\end{tabular}

\subsection{Inductive Analysis}

This section is related to hypotheses testing. In the present research two hypotheses been presented. The first hypothesis states life styles of people and its dimensions differ according to membership or non-membership in face book. Its dimensions include shopping pattern, body management, T-test was applied for independent samples. Table 9 displays the result. Results show that generally the people who are members in facebook and people who aren't have different lifestyles. This result is determined by mean and significance level (sig<0.0.5). In addition, since zero isn't placed in the range of high and low, it can be said life style of people differ according to their membership or nonmembership in face book. About dimension of life style, we can say shopping pattern and cultural consumption of people differ according to their membership or non-membership in face book. However, there is no relation between body management, nutrition pattern and membership or non-membership in face book. This result was achieved since significance level was more than 0.05 and also zero was placed in the range of high and low.

So about body management and nutrition pattern, it can be said that there is no difference based on membership or non-membership in face book.

Table9. Testing the first Hypothesis of the research by T.test for independent samples

\begin{tabular}{|c|c|c|c|c|c|c|}
\hline & membership & mean & T statistic & Significance level & low & High \\
\hline \multirow{2}{*}{ Life style } & Yes & $2 / 9280$ & \multirow{2}{*}{$-2 / 796$} & \multirow{2}{*}{ 0/008 } & \multirow{2}{*}{$-0 / 26822$} & \multirow{2}{*}{$-0 / 04251$} \\
\hline & No & $3 / 0833$ & & & & \\
\hline \multirow{2}{*}{$\begin{array}{l}\text { Shopping } \\
\text { pattern }\end{array}$} & Yes & $3 / 0678$ & \multirow{2}{*}{$-2 / 217$} & \multirow{2}{*}{ 0/011 } & \multirow{2}{*}{$-0 / 46485$} & \multirow{2}{*}{$-0 / 06623$} \\
\hline & No & $3 / 3333$ & & & & \\
\hline
\end{tabular}




\begin{tabular}{|c|c|c|c|c|c|c|}
\hline \multirow{2}{*}{$\begin{array}{l}\text { Body } \\
\text { management }\end{array}$} & Yes & $3 / 0169$ & \multirow{2}{*}{-0.594} & \multirow{2}{*}{ 0/553 } & \multirow{2}{*}{$-0 / 03921$} & \multirow{2}{*}{ 0/07311 } \\
\hline & No & $3 / 0000$ & & & & \\
\hline \multirow{2}{*}{$\begin{array}{l}\text { Nutrition } \\
\text { pattern }\end{array}$} & Yes & 2/7119 & \multirow{2}{*}{-0.413} & \multirow{2}{*}{ 0/682 } & \multirow{2}{*}{$-0 / 39166$} & \multirow{2}{*}{$0 / 25983$} \\
\hline & No & $2 / 7778$ & & & & \\
\hline $\begin{array}{l}\text { Cultural } \\
\text { consumption }\end{array}$ & Yes & $2 / 9153$ & $-2 / 402$ & 0/023 & $-0 / 56792$ & $-0 / 04602$ \\
\hline
\end{tabular}

Second hypothesis states duration of membership in face book and the amount of using it influence life style and its dimensions. Dimensions include shopping pattern, body management, nutrition pattern and cultural consumption. To test this hypothesis, multiple regression was applied. Table 10 display the results. Results suggest that the amount of using face book has the most impact on life style, shopping pattern and cultural consumption. The most effective factor on body management is duration of membership in face book. Duration of connection to face book has greatly influenced nutrition pattern.

Table 10. Testing the second Hypothesis by Multiple Regression

\begin{tabular}{|c|c|c|c|c|c|}
\hline & & R square & Beta & $T$ & Significance level \\
\hline \multirow{3}{*}{ Life style } & Membership duration & \multirow{3}{*}{ 0/050 } & -.053 & -1.007 & .315 \\
\hline & The amount of use & & -.223 & -3.963 & .000 \\
\hline & Connection duration & & .038 & .679 & .498 \\
\hline \multirow{3}{*}{ Shopping pattern } & Membership duration & \multirow{3}{*}{ 0/090 } & .118 & 2.295 & .022 \\
\hline & The amount of use & & -218 & -3.967 & .000 \\
\hline & Connection duration & & -.127 & -2.327 & .021 \\
\hline \multirow{3}{*}{$\begin{array}{l}\text { Body } \\
\text { management }\end{array}$} & Membership duration & \multirow{3}{*}{$0 / 030$} & -172 & -3.230 & 001 \\
\hline & The amount of use & & .044 & .768 & .443 \\
\hline & Connection duration & & .009 & .168 & .867 \\
\hline \multirow{3}{*}{ Nutrition pattern } & Membership duration & \multirow{3}{*}{ 0/012 } & -.049 & -.913 & .362 \\
\hline & The amount of use & & -.082 & -1.440 & .151 \\
\hline & Connection duration & & .087 & 1.528 & .127 \\
\hline \multirow{3}{*}{$\begin{array}{l}\text { Cultural } \\
\text { consumption }\end{array}$} & Membership duration & \multirow{3}{*}{ 0/063 } & -.033 & -.636 & .524 \\
\hline & The amount of use & & -261 & -4.682 & .000 \\
\hline & Connection duration & & .099 & 1.787 & .07 \\
\hline
\end{tabular}

Structural equation model follows this section. The model has been drawn by applying Amos software and as it shows each latent variable includes some dimensions itself.

In this model, there is a correlation coefficient that shows the effect of independent variable" Face book" on the life style of the users. Face book has negative impact on the life style of the users. As figure 8 displays, it equals -0.10 .

Figure 1. Structural equation model

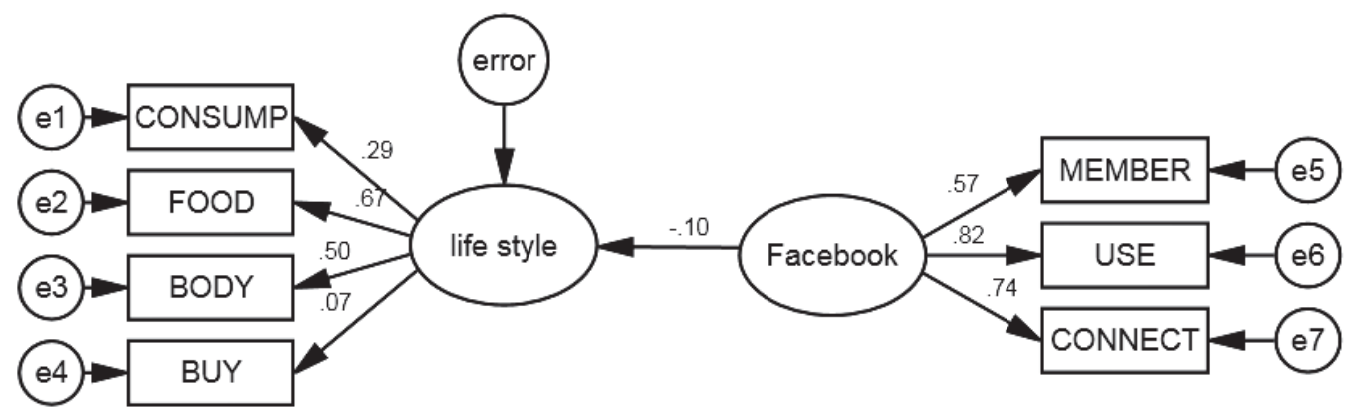


Each variable of face book and life style have been tested with key items. Table 11 displays clarification coefficients achieved by square of factor loadings. In other words, this table displays how much each item can clarify the latent variable.

Table 12. Clarification coefficient of the items of latent variables in the model

\begin{tabular}{|c|c|c|}
\hline Variable & Item & Clarification coefficient \\
\hline \multirow{3}{*}{ Face book } & Membership duration & $0 / 32$ \\
\hline & The amount of use & $0 / 67$ \\
\hline & Connection duration & $0 / 55$ \\
\hline \multirow{4}{*}{ Life style } & Cultural consumption & $0 / 08$ \\
\hline & Nutrition pattern & $0 / 45$ \\
\hline & Body management & $0 / 25^{-}$ \\
\hline & Shopping pattern & $0 / 005$ \\
\hline
\end{tabular}

In table 12, some of the most important Fit indexes, their interpretation and their amount in the model have been displayed. Generally it can be said most of the fit indexes are acceptable or rather acceptable. So the drawn model is a model that can partly conform data with theoretical model. In other words the model shows that empirical data can be covered by theories. Maybe one of the reasons is accurate selection of the dimensions of the latent variable.

Table 13. Fit indexes of model and interpretation of acceptable Fit

\begin{tabular}{|c|c|c|c|c|}
\hline $\begin{array}{c}\text { Model Fit } \\
\text { Index }\end{array}$ & $\begin{array}{c}\text { The amount in } \\
\text { the model }\end{array}$ & Acceptable model & Interpretation & $\begin{array}{c}\text { State of } \\
\text { acceptability }\end{array}$ \\
\hline GFI & $0 / 936$ & $\begin{array}{c}\text { 0(lack of Fit) to1(complete } \\
\text { Fit) }\end{array}$ & $\begin{array}{c}\text { The amount about 0.95 reflects } \\
\text { a suitable Fit }\end{array}$ & Acceptable \\
\hline AGFI & $0 / 892$ & $\begin{array}{c}\text { 0(lack of Fit) to1(complete } \\
\text { Fit) }\end{array}$ & $\begin{array}{c}\text { The amount about 0.95 reflects } \\
\text { a suitable Fit }\end{array}$ & Acceptable \\
\hline RMSEA & $0 / 125$ & Less than 0.05 & $\begin{array}{c}\text { The amount less than } 0.05 \\
\text { shows a good Fit }\end{array}$ & unacceptable \\
\hline TLI & $0 / 90$ & $\begin{array}{c}\text { 0(lack of Fit) to1(complete } \\
\text { Fit) }\end{array}$ & $\begin{array}{c}\text { The amount about 0.95 reflects } \\
\text { a suitable Fit }\end{array}$ & Acceptable \\
\hline NFI & $0 / 88$ & $\begin{array}{c}\text { 0(lack of Fit) to1(complete } \\
\text { Fit) }\end{array}$ & $\begin{array}{c}\text { The amount about 0.95 reflects } \\
\text { a suitable Fit }\end{array}$ & Rather acceptable \\
\hline CMIN.DF & $6 / 898$ & 1 to 5 & $\begin{array}{c}\text { The amount less than } 1 \text { reflects } \\
\text { a weak Fit and more than5 } \\
\text { shows it needs improvement }\end{array}$ & Rather acceptable \\
\hline PNFI & $0 / 51$ & More than 0.50 to 0.60 & Acceptable \\
\hline PCFI & $0 / 506$ & & More than 0.50 to 0.60 & Acceptable \\
\hline
\end{tabular}

\section{Conclusion}

Modern societies have sure changed through communication advancement. Communicative- informative technologies like satellite, internet and virtual social networks have got a position in the society and made lots of changes in the culture and daily lives of people. Since culture flows through mass media, different forms of living are developing. It can be said new media influence the way of living and general tastes in a society. It seem that the growth of the number of internet users and internet social networks has created a new life style the young called virtual life style. This life style integrated with virtual social networks influence all daily activities. The purpose of the present research is analysis of changes in the life style of the young created by introduction and popularity of virtual social networks. In other words, the crucial issue in this study is face book and its consequences on the life style of the young.

The findings of the research suggest that in the field of cultural consumption (cultural affairs), most of face book users prefer to see social dramas and they also like to use artistic works to decorate their rooms and houses. High percentage (over 30\%) of face book users never visit galleries of painting, photo or calligraphy and never participate in art classes. About music, most of them prefer pop music and Iranian traditional music. High percentage of face book users (over 44\%) never listens to heavy metal music. About cultural expenses, most of face book users prefer to spend 
their money on book, shoes and clothed. $5.5 \%$ of them never spend money on computer softwares. About $5 \%$ of them never spend money on sanitary and make up stuff.

Another dimension of life style is nutrition pattern. The results show that most of face book users prefer national and Iranian foods. About $16 \%$ of them never eat foreign foods. Also over $10 \%$ of them pay attention to nutrition patter and agree with its principles like eating breakfast, fruits, vegetable and dairy.

One of the dimensions of life style is free time. The findings suggest that most of face book users prefer to use face book or discuss different topics with their friends in their free time. Large percentage of them never participates in political or religious activities in their free time.

The findings about body management and shopping pattern show that $16.5 \%$ of face book users ignore shopping pattern and disagree with its principle like buying brands, following fashion or shopping in luxurious markets. About body management, some users agree and as many as supporters, some disagree with beauty make up and surgeries.

About two main hypotheses of the research, the research, the result of T-test for independent samples show that the people who are members of face book and people who are not, have different life style. This result was achieved based on mean and significance level (less than 0.05). Also it can be said the findings of the present research conform with findings the previous studies. About the dimensions of life style, it can be said shopping pattern and cultural consumption of people differ based on their membership or non-membership in face book. However, nutrition pattern and body management have no relation with member ship or non-membership in face book, because significance level was more than acceptable amount (0.05) and zero was placed in the range of high and low. And it's possible to have the same mean for the people who are members in face book and the people who are not if another sample had been selected.

So we can conclude there is no relation between membership or non-membership in face book and nutrition pattern and body management.

Second hypothesis state membership duration and the amount of using face book have impact on life style and its dimensions. Life style includes shopping pattern, body management, nutrition pattern and cultural consumption. The result of the multiple regression shoe the amount of using face book has the most impact on life style, shopping pattern and cultural consumption. The most effective factor on body management is duration of membership in face book. Duration of connection to face book has greatly influenced nutrition pattern.

Finally it can be said a lot of changes are being made in different dimensions of life through expansion of communicative-informative technologies; the changes that have result in the change of life style in the age of informative society. The creation of virtual communities has combined various functions of communicative-informative technologies with social life and has changed life style in two ways. First, the increase in hours using internet and browsing internet social networks are direct results of such societies. Second, the changes in the life style of people in the fields of cultural consumption, shopping pattern, body management, clothing style, etc are the effects of virtual communities and new communicative-informative technologies.

\section{References}

Almjeld, Jennifer Marie (2008). The Girls of MySpace, College of Bowling Green State University.

Ameli, S(1387). Culture dual globalization and dual speciation, Iran: Samt. [In Persian]

Ameli, S(1388). Virtual scientific networks, Iran: Institute of social and cultural studies. [in Persian]

Bashir, H., Afrasiabi, M (1391). Virtual social networks and youth lifestyle, Iranian Journal of Cultural Research, 5(1), pp: 31-60.[in Persian]

Bourdieu, Pierre (1984). Distinction, New York: Rout ledge \& Kegan paul.

Boyd, D. M., \& Ellison, N. B. (2008). Social Network Sites: Definition, History, and Scholarship, "Journal of Computer-Mediated Communication", 13(1), 210-230.

Castells, M (2000). The Information Age: Economy, Society and Culture, Blackwell Publishing.

Castells, Manuel (2007). Mobile Communication and Society a Global Perspective, the Information Revolution \& Global Politics. Norwood Mass: Books 24x7.com.

Chaney, David (1996). Fictions of Collective Life; NewYork: Routledge.

Donah, M \& et al(2008). "Social network Sites:Definitions, History and Scholarship", Computer Mediated Communication, Vole 13.

Fazeli, M (1382). Consumption and lifestyle, Iran: Sobhe Sadegh. [In Persian]

Gibbins, J., Reimer, B (1999). The Politics of Postmodernity, London: Sage.

Hilberman, Jessica (2009). Young People are Social Networking in Droves. Retrived. In http//iipdigital.usembassy.gov/st.

Kaffashi, M \& et al. (1389). Investigate the impact of lifestyle on social identity, Journal of Social Research, 3(9), pp: 21-42. [In Persian] Leslie, G. R.\& Larson, R. F. \& Gorman, B. L. (1994). Introductory Sociology, Oxford UN Press. 
Mahdavi Kani, M (1386). Lifestyle, Iranian Journal of Cultural Research, 1(1), pp: 42-60. [In Persian] Mckee, J, B (1969). Introduction to Sociology, Holt Rinehart \& Winston Inc.

Razavizade, N (1386). Investigate the media impact on lifestyle, Iran: Ministry of culture and Islamic guidance. [In Persian]

Shahnooshi, M., Taji, M(1391). The impact of social networks and the lifestyle of the young in Shahrekord, National studies, 13(3), pp: 54- 76. [In Persian]

Shalchi, V (1386). Lifestyle of coffee shop youth, , Iranian Journal of Cultural Research, 1(1), pp: 93-115. [in Persian]

Simmel, G (1990). The Philosophy of Money, Tom Bohomer \& David Frisby (Trans.), Second enlarged Ed., NewYork: Routledge.

Soltanifar, M (1389). New public diplomacy and public relations electronic, Iran: Aspect East. [in Persian]

Tiffany A. Pempek, Yevdokiya A. Yermolayeva, Sandra L. Calvert (2009). College Students' Social Networking Experiences on Face book, "Journal of Applied Developmental Psychology", 30: 227-238. 